\title{
Keterlibatan Orang Tua dalam Meningkatkan Prestasi Belajar Siswa Sekolah Dasar
}

\section{Zulparis $^{1 *}$, Mubarok², Bagus Aulia Iskandar ${ }^{3}$}

1,2,3 Jurusan Pendidikan Guru Sekolah Dasar, STKIP ISM Banjarmasin, Banjarmasin, Indonesia

\author{
A R T I C LE I N F O \\ Article history: \\ Received 2 Januari 2021 \\ Received in revised form \\ 30 Januari 2021 \\ Accepted 24 Maret 2021 \\ Available online 25 April \\ 2021
}

\section{Kata Kunci:}

Keterlibatan Orang Tua,

Prestasi Belajar

Keywords:

Parental Involvement,

Learning Achievement

\begin{abstract}
A B S T R A K
Orang tua merupakan salah satu komponen penting yang berperan dalam proses belajar siswa sekolah dasar. Penelitian ini bertujuan untuk menganalisis hubungan keterlibatan orangtua dengan prestasi belajar siswa. Penelitian ini merupakan penelitian kuantitatif dengan menggunakan pendekatan korelasional. Populasi penelitian adalah siswa kelas $\mathrm{V}$ yang berjumlah 150 siswa. Penentuan sampel dilakukan dengan menggunakan teknik random sampling sehingga diperoleh sampel sebanyak 31 siswa. Pengumpulan data menggunakan tes prestasi belajar dan angket keterlibatan orang tua yang telah diuji validitas dan reliabilitasnya. Data hasil penelitian dianalisis dengan menggunakan analisis regresi sederhana, yang diawali dengan uji prasyarat berupa uji normalitas, linearitas, dan keberartian arah regresi. Hasil penelitian menunjukkan bahwa nilai Sig. $=0.000($ Sig.< 005$)$. Sehingga dapat disimpulkan bahwa adanya hubungan keterlibatan orangtua dengan prestasi belajar siswa. Keterlibatan orangtua berupa peningkatan motivasi belajar yang dapat meningkatkan prestasi belajar siswa menjadi lebih baik. Hal ini disebabkan karena ada dorongan orang tua terhadap anak
\end{abstract} sehingga menimbulkan semangat yang besar tertanam pada diri anak untuk belajar dan mencapai prestasi yang peran orang tua sangat penting dalam perkembangan pada pendidikan anak, akan mengerti dengan pencapaian kegiatan belajar yang dilakukannya untuk mencapai prestasi belajar yang optimal.

\begin{abstract}
A B S T R A C T
Parents are one of the important components that play a role in the learning process of elementary school students. This study aims to analyze the relationship between parental involvement and student achievement. This research is quantitative research using a correlational approach. The population of the study was the fifth-grade students, amounting to 150 students. Determination of the sample is done by using a random sampling technique so that a sample of 31 students is obtained. Collecting data using learning achievement tests and parental involvement questionnaires that have been tested for validity and reliability. The research data were analyzed using simple regression analysis, starting with prerequisite tests in the form of tests for normality, linearity, and the significance of the direction of the regression. The results showed that the value of Sig. $=0.000$ (Sig.<005). So it can be concluded that there is a relationship between parental involvement and student achievement. Parental involvement is in the form of increasing learning motivation which can improve student learning achievement for the better. This is because there is a parent's encouragement to the child so that it creates a great enthusiasm embedded in the child to learn and achieve achievement. The role of parents is very important in the development of children's education, will understand the achievement of the learning activities they do to achieve optimal learning achievement.
\end{abstract}

\section{Pendahuluan}

Pendidikan merupakan suatu usaha yang bersifat sadar dan terencana yang dilaksanakan sebagai upaya untuk membentuk manusia seutuhnya (Bai \& Chen, 2008; Harahap et al., 2019). Ada banyak komponen yang terlibat dalam proses penyelenggaraan pendidikan. Komponen tersebut diantaranya adalah pendidik, sarana prasarana, dukungan masyarakat, dan keterlibatan orang tua. Keterlibatan orang tua dalam pendidikan dapat berupa aktivitas yang dilakukan orang tua, baik di 
rumah maupun di sekolah, sehingga akan memberikan manfaat bagi siswa, orang tua, maupun sekolah (Bai \& Chen, 2008; Park et al., 2010). Faktor yang mempengaruhi keberhasilan belajar siswa dalam kegiatan belajar mengajar adalah kurangnya pendekatan dan keterlibatan orangtua yang membuat siswa kurang efektif dalam mendapatkan pembelajaran (Aini et al., 2016; Diadha, 2015; Englund et al., 2004). Kewajiban orang tua mulai dari anak belum bisa berpikir sampai bisa mempertanggung jawabkan perbuatannya sendiri. Untuk itu pengaruh keterlibatan orangtua sangatlah penting dalam proses perkembangan anak saat belajar (Mansur, 2005; Morrison, 1988).

Keterlibatan orang tua pada pendidikan akan diperlukan pada tiap jenjang pendidikan dan pendidikan lembaga dimana murid masih baru mulai pembentukan karakter melalui perkembangan sikap, moral, agama dan sosial sehingga diperlukan keterlibatan orang tua dalam pendidikan anak (Hedyanti et al., 2016; Samuel et al., 2016). Hal tersebut demi terciptanya kesamaan persepsi dan isi pendidikan anak yang diharapkan mampu menunjang terjadinya kesinambungan antara pendidikan di rumah dan sekolah. Keterlibatan orang tua terbagi menjadi tiga macam. Pertama, kerja sama antara orang tua dan guru sebagai penolong. Kedua, merupakan proses pelaksanan yang melaluai lampau. Ketiga, proses dimana guru dan orang tua bekerja, belajar dan berpartisipasi dalam membuat keputusan (Acar et al., 2021; Morrison, 1988). Keterlibatan orang tua pada pendidikan anak merupakan bentuk aktifitas yang diterapkan oleh orang tua melalui kerja sama dirumah maupun sekolah (Diadha, 2015; Hoover-Dempsey \& Sandler, 1995).

Pada dasarnya orangtua tidak selalu aktif dalam pendidikan anak bahkan tidak peduli dengan hasil belajar anaknya padahal penting sekali keterlibatan orangtua dalam masa perkembangan anakanak (Gonzalez-DeHass et al., 2005; Jeynes, 2010; Sui-Chu \& Willms, 1996). Pendidikan anak tidak bisa lepas dari perhatian atau keterlibatan orang tua tapi masih banyak orangtua seakan tidak peduli dengan anak mereka. Pada saat sekolah mereka hanya menyiapkan materiil tapi tidak memberikan dukungan yang melibatakan mereka dalam Pendidikan. Keterlibatan orang tua begitu strategis untuk meningkatkan prestasi belajar anak, Hal ini sejalan dengan penelitian terdahulu yang menemukan bahwa keterlibatan orang tua mempunyai pengaruh signitifikan terhadap pencapain prestasi akademik anak (Gonzalez-DeHass et al., 2005; Hoover-Dempsey et al., 2001; Jeynes, 2010; Sui-Chu \& Willms, 1996).

Keterlibatan orang tua didefinisikan sebagai segala bentuk aktivitas yang dilakukan oleh orang tua dalam rangka memberikan dukungan terhadap aktivitas belajar siswa (Driessen et al., 2005; Hornby \& Lafaele, 2011). Aktivitas tersebut dapat melalui kerjasama dengan guru, masyarakat, atau antar anggota keluarga, yang dilakukan di rumah maupun di sekolah. Keterlibatan ini bertujuan untuk memaksimalkan perkembangan pendidikan anak, sehingga memberikan dampak positif terhadap siswa, orang tua, dan sekolah (Fan, 2001). Keterlibatan orang tua dalam pendidikan siswa dapat memberikan manfaat bagi siswa, orang tua, dan guru atau sekolah. Adapun salah satu manfaat keterlibatan orang tua adalah meningkatkan motivasi siswa untuk hadir di sekolah, kualitas sikap dan perilaku siswa di sekolah, dan kesiapan siswa dalam mengikuti pembelajaran di sekolah. Selain itu, keterlibatan orang tua juga dapat meningkatkan prestasi belajar siswa. Hal ini sejalan dengan penelitian terdahulu yang menunjukkan bahwa keterlibatan orang tua memberikan kontribusi positif terhadap prestasi belajar siswa (Chu, 2014; Jeynes, 2010; Saleh \& Kim, 2009; Sui-Chu \& Willms, 1996).

Penelitian ini bertujuan untuk menganalisis hubungan keterlibatan orangtua dengan prestasi belajar siswa. Peran orang tua di rumah adalah sebagai guru kedua. Tugas orang tua yang paling penting terletak pada tugas edukasi (mendidik). Tugas ini terlihat pada pola asuh yang diterapkan pada seorang anak. Orang tua dan guru memegang peran penting dalam perkembangan umum anak, khususnya dalam belajar anak. Efek dari keterlibatan orang tua dalam belajar anak salah satunya adalah anak menjadi sukses dalam pembelajaran disekolah, karena orang tua mendukung dan terlibat dalam pendidikan anak kegiatan belajar anak disekolah terbatas sedangkan waktu terbanyak merupakan tanggung jawab orang tua di rumah keterlibatan orang tua di rumah berupa membimbing belajar dan dukungan lain agar anak bisa mencapai prestasinya di sekolah. Keterlibatan orang tua dalam belajar anak sangat dibutuhkan khususnya pada anak diusia sekolah (Hedyanti et al., 2016; Hornby \& Lafaele, 2011; Sui-Chu \& Willms, 1996).

\section{Metode}

Penelitian ini adalah penelitian kuantitatif dengan menggunakan pendekatan penelitian korelasional, yaitu penelitian yang bertujuan untuk mengetahui dan menganalisis hubungan antara 
variabel independen dan dependen (Arikunto, 2014; Sugiyono, 2018). Adapun variabel yang terlibat dalam penelitian ini adalah keterlibatan orang tua sebagai variabel independen, dan prestasi belajar siswa sebagai variabel dependen. Adapun rancangan penelitian yang digunakan disajikan pada Gambar 1.

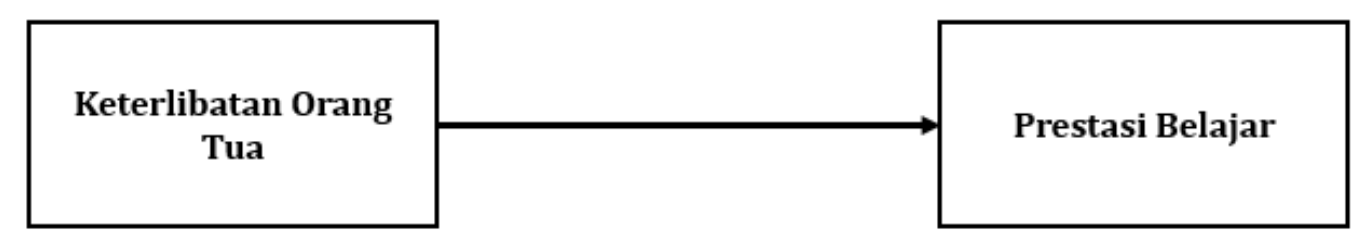

Gambar 1. Rancangan Penelitian

Populasi dalam penelitian ini melibatkan sebanyak 150 siswa kelas V sekolah dasar. Pengambilan sampel dalam penelitian ini menggunakan teknik random sampling. Teknik random sampling merupakan teknik pengambilan sampel yang dilakukan secara random/acak dalam suatu kelompok populasi (Sugiyono, 2018). Berdasarkan hasil pengambilan sampel, diperoleh sebanyak 31 orang siswa yang menjadi sampel dalam penelitian ini. Data yang dikumpulkan dalam penelitian ini meliputi data keterlibatan orang tua dan data prestasi belajar. Metode pengumpulan data dalam penelitian ini menggunakan metode tes dan non tes. Metode tes yang digunakan berbentuk tes prestasi belajar, dan metode non tes yang digunakan adalah kuesioner keterlibatan orang tua. Instrumen penelitian yang digunakan dalam penelitian ini telah melalui serangkaian uji untuk memastikan validitas dan reliabilitasnya. Uji validitas dan reliabilitas sangat penting dilakukan untuk memastikan keakuratan instrumen yang digunakan dalam penelitian. Data-data yang telah dikumpulkan, kemudian dianalisis statistik secara deskriptif dan inferensial. Metode analisis data dalam penelitian ini menggunakan analisis regresi sederhana. Sebelum dilakukan analisis regresi sederhana, terlebih dahulu dilakukan beberapa uji prasyarat analisis, yaitu uji normalitas sebaran data, uji linearitas, dan keberartian arah regresi. Setelah memenuhi ketiga prasyarat tersebut, analisis dilanjutkan dengan analisis regresi sederhana untuk menganalisis pengaruh variabel keterlibatan orang tua terhadap prestasi belajar. Analisis dilakukan dengan menggunakan bantuan aplikasi IBM SPSS Statistics 21.0 for Windows

\section{Hasil dan Pembahasan \\ Hasil}

\section{Hasil Analisis Deskriptif}

Hasil analisis deskriptif data disajikan pada Tabel 1.

Tabel 1. Hasil Analisis Deskriptif

\begin{tabular}{cccccc}
\hline Variabel & $\mathrm{N}$ & Minimum & Maksimum & Mean & Standar Deviasi \\
\hline Keterlibatan Orang Tua & 31 & 46.00 & 60.00 & 55.4516 & 4.02359 \\
Prestasi Belajar & 31 & 51.00 & 95.00 & 83.3548 & 14.55919 \\
\hline
\end{tabular}

\section{Hasil Uji Prasyarat Analisis}

Uji prasyarat analisis yang dilakukan dalam penelitian ini meliputi uji normalitas, linearitas dan keberartian arah regresi. Hasil Uji Normalitas disajikan pada Tabel 2.

Tabel 2. Hasil Uji Normalitas

\begin{tabular}{cccccccc}
\hline \multirow{2}{*}{ Variabel } & \multicolumn{3}{c}{ Kolmogorov-Smirnova } & \multicolumn{3}{c}{ Shapiro-Wilk } \\
\cline { 2 - 8 } & Statistic & df & \multicolumn{1}{c}{ Sig. } & Statistic & df & Sig. \\
\hline Keterlibatan Orang Tua & .095 & 31 & .200 & .987 & 31 & .970 \\
\hline Prestasi Belajar & .139 & 31 & .146 & .964 & 31 & .387 \\
\hline
\end{tabular}


Berdasarkan hasil analisis uji normalitas, nilai signifikansi (Kolmogorov-Smirnov) data keterlibatan orang tua sebesar 0,200; dan data prestasi belajar sebesar 0,146. Berdasarkan hasil tersebut, dapat dapat dilihat bahwa nilai Sig. > 0,05 untuk semua kelompok data. Sehingga dapat disimpulkan bahwa kedua kelompok data tersebut berdistribusi normal. Selanjutnya uji prasyarat analisis dilanjutkan dengan uji linearitas dan keberartian arah regresi. Adapun hasil uji linearitas dan keberartian arah regresi disajikan pada Tabel 3.

Tabel 3. Hasil Uji Linearitas dan Keberartian Arah Regresi

\begin{tabular}{|c|c|c|c|c|c|c|c|}
\hline \multicolumn{3}{|c|}{ Variable } & $\begin{array}{c}\text { Sum of } \\
\text { Squares }\end{array}$ & df & $\begin{array}{c}\text { Mean } \\
\text { Square }\end{array}$ & $\mathbf{F}$ & Sig. \\
\hline \multirow{5}{*}{$\begin{array}{l}\text { Prestasi Belajar* } \\
\text { Keterlibatan Orang } \\
\text { Tua }\end{array}$} & & (Combined) & 5927.097 & 10 & 592.710 & 27.440 & .001 \\
\hline & Between & Linearity & 4216.489 & 1 & 4216.489 & 195.208 & .000 \\
\hline & Groups & $\begin{array}{l}\text { Deviation from } \\
\text { Linearity }\end{array}$ & 1710.608 & 9 & 190.068 & 8.799 & .160 \\
\hline & \multirow{2}{*}{\multicolumn{2}{|c|}{ Within Groups }} & 432.000 & 20 & 21.600 & & \\
\hline & & & 6359.097 & 30 & & & \\
\hline
\end{tabular}

Hasil analisis uji linearitas menunjukkan nilai signifikansi (Deviation from Linearity) sebesar 0,160. Berdasarkan hasil tersebut, dapat dapat dilihat bahwa nilai Sig. $>0,05$. Sehingga dapat disimpulkan bahwa data tersebut memiliki hubungan yang linier. Selanjutnya, hasil analisis uji keberartian arah regresi menunjukkan nilai signifikansi (Linearity) sebesar 0,000. Berdasarkan hasil tersebut, dapat dapat dilihat bahwa nilai Sig. < 0,05. Sehingga dapat disimpulkan bahwa variabel prestasi belajar dan keterlibatan orang tua memiliki arah regresi yang berarti. Ketiga prasyarat analisis telah terpenuhu, sehingga analisis dapat dilanjutkan dengan analisis regresi sederhana.

\section{Hasil Analisis Regresi Sederhana}

Hasil analisis regresi sederhana dapat dilihat pada Tabel 4.

Tabel 4. Hasil Analisis Regresi Sederhana

\begin{tabular}{|c|c|c|c|c|c|c|}
\hline & \multirow[t]{2}{*}{ Variable } & \multicolumn{2}{|c|}{ Unstandardized Coefficients } & \multirow{2}{*}{$\begin{array}{c}\begin{array}{c}\text { Standardized } \\
\text { Coefficients }\end{array} \\
\text { Beta } \\
\end{array}$} & \multirow[t]{2}{*}{$\mathbf{t}$} & \multirow[t]{2}{*}{ Sig. } \\
\hline & & B & Std. Error & & & \\
\hline & (Constant) & 31.281 & 6.878 & & 4.548 & .000 \\
\hline 1 & $\begin{array}{l}\text { Keterlibatan Orang } \\
\text { Tua }\end{array}$ & 2.946 & .390 & .814 & 7.554 & .000 \\
\hline
\end{tabular}

Berdasarkan persamaan regresi di atas, koefisien regresi 2.946 menandakan bahwa setiap terjadi peningkatan satu satuan X (Keterlibatan Orang Tua), maka Y (Prestasi Belajar) akan mengalami peningkatan sebesar 2.946, begitu pula sebaliknya. Nilai Sig. yang ditunjukkan pada Tabel 4 adalah sebesar $0.000(<0.05)$, sehingga dapat diinterpretasikan bahwa koefisien regresi signifikan atau keterlibatan orang tua berpengaruh secara nyata terhadap prestasi belajar siswa.

\section{Pembahasan}

Hasil penelitian menunjukkan bahwa keterlibatan orang tua berpengaruh nyata terhadap prestasi belajar siswa. Keterlibatan orangtua mempunyai hubungan yang kuat terhadap prestasi belajar anak, sama halnya jika keterlibatan orangtua tidak ada maka akan menyebabkan kemalasan belajar dan prestasi akan rendah. Hal ini sejalan dengan pendapat yang mengemukakan bahwa konsep keterlibatan orang tua bukanlah hal baru di lingkungan pendidikan dan telah memainkan peran dalam peningkatan kualitas belajar siswa (Gonzalez-DeHass et al., 2005; Hoover-Dempsey et al., 2001; 
Samuel et al., 2016). Selain itu, peran orangtua begitu tepat dan strategis pada pendidikan anak usia dini pada masa pertumbuhan anak menuju kedewasan (Aini et al., 2016; Englund et al., 2004). Pada dasarnya orangtua tidak selalu aktif dalam pendidikan anak bahkan tidak peduli dengan hasil belajar anaknya padahal penting sekali keterlibatan orangtua dalam masa perkembangan anak-anak. Pendidikan anak tidak bisa lepas dari perhatian atau keterlibatan orang tua tapi masih banyak orangtua seakan tidak peduli dengan anak mereka (Ginanjar, 2017; Gunadi, 2 C.E.). Pada saat sekolah mereka hanya menyiapkan materiil tapi tidak memberikan dukungan yang melibatakan mereka dalam Pendidikan. Keterlibatan orang tua begitu strategis untuk meningkatkan prestasi belajar anak, Hal ini sejalan dengan penelitian terdahulu yang menemukan bahwa keterlibatan orang tua mempunyai pengaruh signitifikan terhadap pencapain prestasi akademik anak (Acar et al., 2021; Hoover-Dempsey \& Sandler, 1995).

Keterlibatan orang tua didefinisikan sebagai segala bentuk aktivitas yang dilakukan oleh orang tua dalam rangka memberikan dukungan terhadap aktivitas belajar siswa (Driessen et al., 2005; Hornby \& Lafaele, 2011). Aktivitas tersebut dapat melalui kerjasama dengan guru, masyarakat, atau antar anggota keluarga, yang dilakukan di rumah maupun di sekolah. Keterlibatan ini bertujuan untuk memaksimalkan perkembangan pendidikan anak, sehingga memberikan dampak positif terhadap siswa, orang tua, dan sekolah (Fan, 2001). Keterlibatan orang tua dalam pendidikan siswa dapat memberikan manfaat bagi siswa, orang tua, dan guru atau sekolah. Adapun salah satu manfaat keterlibatan orang tua adalah meningkatkan motivasi siswa untuk hadir di sekolah, kualitas sikap dan perilaku siswa di sekolah, dan kesiapan siswa dalam mengikuti pembelajaran di sekolah (Harahap et al., 2019; Park et al., 2010; Sangadji, 2016). Selain itu, keterlibatan orang tua juga dapat meningkatkan prestasi belajar siswa (Irma et al., 2019; Kaso et al., 2021; Yoga et al., 2015). Hal ini sejalan dengan penelitian terdahulu yang menunjukkan bahwa keterlibatan orang tua memberikan kontribusi positif terhadap prestasi belajar siswa (Chu, 2014; Jeynes, 2010; Saleh \& Kim, 2009; Sui-Chu \& Willms, 1996).

Hasil penelitian ini berimplikasi pada pentingnya meningkatkan peran serta orang tua dalam proses pendidikan dan pembelajaran anaknya. Korelasi positif yang kuat antara keterlibatan orang tua dengan prestasi belajar siswa mengharuskan orang tua untuk senantiasa mendampingi, membimbing, dan memberikan motivasi kepada anaknya untuk belajar (Hung et al., 2012; Orrell, 2006; Wei et al., 2015). Keterlibatan ini sangat berguna untuk meningkatkan motivasi dan kemauan siswa untuk belajar, yang nantinya akan berdampak pada peningkatan prestasi belajar siswa (Hwang et al., 2013). Penelitian ini memiliki keterbatasan dalam mengeksplorasi variabel-variabel yang memiliki kecenderungan dapat mempengaruhi prestasi belajar siswa. Berdasarkan hal tersebut, direkomendasikan kepada peneliti berikutnya untuk mengeksplorasi lebih jauh mengenai faktor lain yang dapat mempengaruhi prestasi belajar siswa. Selain itu, lingkup penelitian hendaknya lebih diperluas untuk mendapatkan hasil temuan penelitian yang lebih representatif.

\section{Simpulan}

Terdapat korelasi positif antara keterlibatan orang tua dengan prestasi belajar. Hal ini disebabkan karena ada dorongan orang tua terhadap anak sehingga menimbulkan semangat yang besar tertanam pada diri anak untuk belajar dan mencapai prestasi yang peran orang tua sangat penting dalam perkembangan pada pendidikan anak, akan mengerti dengan pencapaian kegiatan belajar yang dilakukannya untuk mencapai prestasi belajar yang optimal. Keterlibatan orang tua begitu strategis untuk meningkatkan prestasi belajar anak. Korelasi positif yang kuat antara keterlibatan orang tua dengan prestasi belajar siswa mengharuskan orang tua untuk senantiasa mendampingi, membimbing, dan memberikan motivasi kepada anaknya untuk belajar. Keterlibatan ini sangat berguna untuk meningkatkan motivasi dan kemauan siswa untuk belajar, yang nantinya akan berdampak pada peningkatan prestasi belajar siswa.

\section{Daftar Pustaka}

Acar, S., Chen, C. I., \& Xie, H. (2021). Parental involvement in developmental disabilities across three cultures: A systematic review. Research in Developmental Disabilities, 110. https://doi.org/10.1016/j.ridd.2021.103861.

Aini, D. F. N., Hanurawan, F., \& Hariyono, H. (2016). Pengembangan motivasi belajar siswa berprestasi anak Tenaga kerja Indonesia (studi kasus pada siswa sekolah dasar di Kabupaten Blitar). Jurnal 
Pendidikan: Teori, Penelitian, Dan Pengembangan, 1(9), 1875-1879. https://doi.org/10.17977/jp.v1i9.6865.

Arikunto, S. (2014). Metode Penelitian Kuantitatif, Kualitatif, dan Kombinasi (Mixed Methods). Alfabeta.

Bai, S. M., \& Chen, S. M. (2008). Evaluating students' learning achievement using fuzzy membership functions and fuzzy rules. Expert Systems with Applications, 34(1), 399-410. https://doi.org/10.1016/j.eswa.2006.09.010.

Chu, H. C. (2014). Potential negative effects of mobile learning on students' learning achievement and cognitive load-A format assessment perspective. Journal of Educational Technology \& Society, 17(1), 332-344. https://www.jstor.org/stable/pdf/jeductechsoci.17.1.332.pdf.

Diadha, R. (2015). Keterlibatan orang tua dalam pendidikan anak usia dini di taman kanak-kanak. Edusentris: Jurnal Ilmu Pendidikan, 2(1), 61-71. https://doi.org/10.17509/edusentris.v2i1.161.

Driessen, G., Smit, F., \& Sleegers, P. (2005). Parental involvement and educational achievement. British Educational Research Journal, 31(4), 509-532. https://doi.org/10.1080/01411920500148713.

Englund, M. M., Luckner, A. E., Whaley, G. J., \& Egeland, B. (2004). Children's achievement in early elementary school: Longitudinal effects of parental involvement, expectations, and quality of assistance. Journal of educational psychology. Journal of Educational Psychology, 96(4), 723. https://psycnet.apa.org/record/2004-21454-010.

Fan, X. (2001). Parental involvement and students' academic achievement: A growth modeling analysis. The Journal of Experimental Education, 70(1), 27-61. https://doi.org/10.1080/00220970109599497.

Ginanjar, M. H. (2017). Keseimbangan peran orang tua dalam pembentukan karakter anak. Edukasi Islami: Jurnal Pendidikan Islam, 2(3). https://doi.org/10.30868/ei.v2i03.2.

Gonzalez-DeHass, A. R., Willems, P. P., \& Holbein, M. F. D. (2005). Examining the relationship between parental involvement and student motivation. Educational Psychology Review, 17(2), 99-123. https://doi.org/10.1007/s10648-005-3949-7.

Gunadi, T. A. (2 C.E.). Pentingnya Peran Serta Orang Tua dalam Peningkatan Mutu Pendidikan di SMK. Jurnal Pendidikan Dasar Dan Menengah (JUPEDASMEN), 1. http://jupedasmen.com/index.php/JUPEDASMEN/article/view/61.

Harahap, F., Nasution, N. E. A., \& Manurung, B. (2019). The Effect of Blended Learning on Student's Learning Achievement and Science Process Skills in Plant Tissue Culture Course. International Journal of Instruction, 12(1), 521-538. https://eric.ed.gov/?id=EJ1201370.

Hedyanti, W. N., Sudarmiatin, S., \& Utaya, S. (2016). Pengaruh Pola Asuh Orangtu A terhadap Prestasi Belajar IPS melalui Motivasi Belajar (Studi pada Siswa Kelas IV, V, VI Gugus 2 Kecamatan Ngantang Kabupaten Malang). Jurnal Pendidikan: Teori, Penelitian, Dan Pengembangan, 1(5), 865-873. https://doi.org/10.17977/jp.v1i5.6289.

Hoover-Dempsey, K., \& Sandler, H. (1995). Parental involvement in children. Teachers College Record, 97(2), 310-331. https://www.tcrecord.org/Content.asp?ContentId=1406

Hoover-Dempsey, K. V., Battiato, A. C., Walker, J. M., Reed, R. P., DeJong, J. M., \& Jones, K. P. (2001). Parental involvement in homework. Educational Psychologist, 36(3), 195-209. https://doi.org/10.1207/S15326985EP3603_5.

Hornby, G., \& Lafaele, R. (2011). Barriers to parental involvement in education: An explanatory model. Educational Review, 63(1), 37-52. https://doi.org/10.1080/00131911.2010.488049

Hung, C. M., Hwang, G. J., \& Huang, I. (2012). A project-based digital storytelling approach for improving students' learning motivation, problem-solving competence and learning achievement. Journal of Educational Technology \& Society, 15(4), 368-379. https://www.jstor.org/stable/pdf/jeductechsoci.15.4.368.pdf.

Hwang, G. J., Wu, P. H., Zhuang, Y. Y., \& Huang, Y. M. (2013). Effects of the inquiry-based mobile learning model on the cognitive load and learning achievement of students. Interactive Learning Environments, 21(4), 338-354. https://doi.org/10.1080/10494820.2011.575789l.

Irma, C. N., Nisa, K., \& Sururiyah, S. K. (2019). Keterlibatan orang tua dalam pendidikan anak usia dini di TK Masyithoh 1 Purworejo. Jurnal Obsesi: Jurnal Pendidikan Anak Usia Dini, 3(1), 214-224. https://doi.org/10.31004/obsesi.v3i1.152.

Jeynes, W. (2010). Parental involvement and academic success. Routledge.

Kaso, N., Nurjihad, A., Ilham, D., \& Aswar, N. (2021). Facebook and its Impact on Students' Learning Achievement at State Islamic High School of Palopo. Jurnal Studi Guru Dan Pembelajaran, 4(1), 
1-15. https://doi.org/10.30998/sap.v1i2.1023.

Mansur. (2005). Pendidikan Usia Dini Dalam Islam. Pustaka Pelajar.

Morrison, G. S. (1988). Education and Development of Infants, Toddlesr, and Preschoolers. Scott Foresman and Company.

Orrell, J. (2006). Feedback on learning achievement: rhetoric and reality. Teaching in Higher Education, 11(4), 441-456. https://doi.org/10.1080/13562510600874235.

Park, J. H., Lee, E. H., \& Bae, S. H. (2010). Factors influencing learning achievement of nursing students in e-learning. Journal of Korean Academy of Nursing, 40(2), 182-190. https://doi.org/10.4040/jkan.2010.40.2.182.

Saleh, I., \& Kim, S. I. (2009). A fuzzy system for evaluating students' learning achievement. Expert Systems with Applications, 36(3), 6236-6243. https://doi.org/10.1016/j.eswa.2008.07.088.

Samuel, D., Utaya, S., \& Malikhah, T. S. (2016). Pengaruh Dukungan Orang tua, Kompetensi Pedagogik Guru, Dan Motivasi Belajar Terhadap Prestasi Belajar IPS Siswa [Universitas Negeri Malang]. https://karya-ilmiah.um.ac.id.259-484.

Sangadji, S. (2016). Implementation of cooperative learning with group investigation model to improve learning Achievement of vocational school students in Indonesia. International Journal of Learning and Development, 6(1), 91-103. https://ideas.repec.org/a/mth/ijld88/v6y2016i1p91-103.html.

Sugiyono. (2018). Metode Peneiltian Kuantitatif, Kualitatif dan R\&D. In Alfabeta Bandung.

Sui-Chu, E. H., \& Willms, J. D. (1996). Effects of parental involvement on eighth-grade achievement. Sociology of Education, 126-141. https://doi.org/10.2307/2112802.

Wei, H. C., Peng, H., \& Chou, C. (2015). Can more interactivity improve learning achievement in an online course? Effects of college students' perception and actual use of a course-management system on their learning achievement. Computers \& Education, 83, 10-21. https://doi.org/10.1016/j.compedu.2014.12.013.

Yoga, D. S., Suarmini, N. W., \& Prabowo, S. (2015). Peran keluarga sangat penting dalam pendidikan mental, karakter anak serta budi pekerti anak. Jurnal Sosial Humaniora (JSH), 8(1), 46-54. https://doi.org/10.12962/j24433527.v8i1.1241. 